\title{
Combining Legume Groundcovers and Low Nitrogen Fertilization in a Short-rotation Fraser Fir (Abies fraseri) Cropping System: Effect on Productivity, Soil Fertility, and Nutrient Leaching
}

\author{
Yingqian Lin ${ }^{1}$, Alexa R. Wilson ${ }^{1}$, and Pascal Nzokou ${ }^{2,3}$ \\ Department of Forestry, Michigan State University, 126 Natural Resources \\ Bldg, East Lansing, MI 48824
}

Additional index words. groundcovers, cropping systems, soil mineral nitrogen, Christmas trees, nitrate leaching

\begin{abstract}
High rates of inorganic fertilizers are used in conventional intensive production systems such as Abies fraseri (fraser fir) cropping systems for Christmas trees. Groundcovers can be used as green mulches, help reduce the use of farm chemicals, and provide several environmental benefits. We investigated the performance of a low-input cropping system by combining two legume cover crops [Dutch white clover (Trifolium repens) and alfalfa (Medicago sativa)] in combination with low rates of inorganic fertilizers as a step toward a more sustainable production system. The randomized block design comprised one cover crop and one of three applications of reduced rate inorganic fertilizer $(75 \%$, $\mathbf{5 0} \%$, and $\mathbf{2 5 \%}$ of the recommended rate). A conventional system using herbicides for weed control and the $100 \%$ rate of inorganic fertilizer was used as a control. Parameters measured included tree morphology, foliar nitrogen concentration, soil mineral nitrogen, and nitrate-N leaching below the root zone. A significant positive growth response (height and diameter) was obtained in all alfalfa-based cropping systems. This was accompanied by foliar nutrient concentrations similar to conventional plots and a reduction in nitrate$\mathrm{N}$ leaching. However, in white clover-based cropping systems, the growth response was reduced (both height and diameter), suggesting competition for soil resources. In addition, the total nitrate-N leaching was higher in this system, suggesting an imbalance between mineral nitrogen availability and use in white clover-based cropping systems. We conclude that if the potential competition between cover crops and trees can be properly managed, legume cover crops can be effectively used to make intensive production tree-based systems more sustainable. Further studies related to mineralization and macronutrient flows are needed before any definite recommendation can be made about the use of these systems in large-scale production systems.
\end{abstract}

In conventional agricultural and forestry production systems, inorganic fertilizers are widely used. However, approximately half of the applied fertilizers are lost from the systems before the cash crops can assimilate them (Drinkwater et al., 1998). In addition to their high cost that can negatively affect profitability, the long-term use of fertilizers can also have serious negative environmental effects such as increasing soil acidity, soil erosion, and degradation of soil biodiversity, eventually leading to loss of productivity for the target crop (Juo et al., 1995).

Conversely, using groundcovers can bring several potential advantages to the sustainability

\footnotetext{
Received for publication 9 Nov. 2010. Accepted for publication 28 Jan. 2011.

${ }^{1}$ Research Assistant.

${ }^{2}$ Assistant Professor.

${ }^{3}$ To whom reprint requests should be addressed; e-mail Nzokoupa@msu.edu.
}

of intensive forestry and agricultural production systems. Groundcovers can contribute organic matter to soil and reduce soil compaction and crusting, thus improving water infiltration and in some cases moisture retention (MacRae and Mehuys, 1985). They also have the ability to reduce soil erosion by wind and water (Hargrove, 1991), add or retain soil nitrogen $(\mathrm{N})$, facilitate the availability of other nutrients like phosphorous and calcium (Kourik, 1986), suppress weeds, and improve chemical and physical characteristics of soil (Giller and Wilson, 2000).

Examples of successful use of cover crops in cropping systems include soybean (Reddy, 2001), corn (Vaughan and Evanylo, 1998), wheat (Bakht et al., 2009), palm oil, rubber plantations, and various orchard and vineyard production systems (Baumgartner et al., 2008). For example, the incorporation of cover crops has proven to significantly reduce nitrate leaching in rubber tree plantations (Schroth et al., 2001) and in cereal grass-based systems where they are reported to be more efficient in the uptake of residual soil $\mathrm{N}$ (Meisinger et al., 1991; Shipley et al., 1992). Brinsfield and Staver (1991) reported that perennial ryegrass exhibited the best response with regard to the absorption of unused soil $\mathrm{N}$ as a result of its quick-growing and fibrous root system.

However, intercropping systems are known to be complex ecosystems in which both facilitation and competitive interactions may occur. In tree-cover crop systems with relatively wide spacing, the competition for resources is mainly belowground (Hanninen, 1998). The aboveground abiotic factors, e.g., light, temperature, and humidity, are usually of minor importance (Casper and Jackson, 1997; Köchy and Wilson, 1997). In belowground competition, plants reduce the available soil resources, mainly water and mineral nutrients, and decrease the growth and success of their neighbors (Casper and Jackson, 1997). In general, it has been suggested that root competition is more important than shoot competition and has a greater impact on plant performance (Gerry and Wilson, 1995; Weiner et al., 1997; Wilson, 1988).

As a result of these potentially negative consequences, growers and farm managers tend to be very concerned about introducing cover crops when they have an existing functional inorganic fertilization program. Consequently, the use of groundcovers in agroforestry and other types of short rotation tree production systems such as Christmas tree plantation and woody biomass plantations is relatively limited.

A logical intermediary step is to determine reduced fertilization levels combined with cover crops that can be acceptable as a first-step, low-risk option for growers but still provide the same ecological and environmental benefits that groundcovers bring to the sustainability of cropping systems. This study explored the effects of combining legume cover crops with low rates of inorganic fertilizers. The overall aim of this project was to develop low-input sustainable farming systems for fraser fir production that will meet the nutritional requirements of trees and improve soil fertility while reducing nutrient losses to leaching.

The specific objectives of were to 1) examine the effects of combining legume cover crops with low rates of $\mathrm{N}$ fertilization on fraser fir productivity and nutrient status; 2) evaluate the impact on soil fertility (nitrate$\mathrm{N}$ ); and 3) determine the impact of these cropping systems on nutrient leaching below the root zone.

\section{Material and Methods}

\section{Site description}

The experiment was conducted in 2009 and 2010 at Sandhill Farm of the Tree Research Center (long. $42^{\circ} 65^{\prime} \mathrm{N}$, lat. $84^{\circ} 42^{\prime} \mathrm{E}$ ) on the campus of Michigan State University in East Lansing, MI. The average summer and winter temperatures are 15.5 and $-6.6{ }^{\circ} \mathrm{C}$, respectively. Annual average precipitation is $853 \mathrm{~mm}$ with rainfall distributed fairly evenly 
throughout the year. The soil at Sandhill is a Mariette fine sandy loam soil, which is classified as moderately well drained with high available water capacity and medium surface runoff. The experimental field was surrounded by a three-wire double electric fence to prevent deer damage.

\section{Experimental design and plant materials}

The field was $39 \times 64 \mathrm{~m}$ in size, and the experiment was established as a randomized complete block design with three replications. Each experimental plot was $7.2 \times 10.8 \mathrm{~m}$ and contained 35 trees established at $1.8 \times 1.8-\mathrm{m}$ spacing. The field was established in 2007 using fraser fir transplants (plugs +2 ) obtained from a local commercial nursery (Peterson's Riverview Nursery, Allegan, MI). Transplants were machine planted on 8 May 2007. Plants in border rows were used as a buffer and not included in measurements, therefore restricting data collection to the area of the remaining 15 interior trees in each plot.

Two legume cover crops-Dutch white clover (Trifolium repens) and alfalfa (Medicago sativa)-were seeded between preplanted rows of fraser fir trees. The cover crop seeds were purchased from Michigan State Seeds Company (Grand Ledge, MI) and hand-broadcasted on 15 May 2007 at seeding rates of $28 \mathrm{~kg} \cdot \mathrm{ha}^{-1}$ for both species.

A total of seven treatments was applied, including a bare ground conventional control with $100 \%$ of the recommended rate of inorganic nitrogen (BG100); three alfalfa treatments combining alfalfa groundcovers in combination with each of $25 \%, 50 \%$, and $75 \%$ of the recommended rate of inorganic nitrogen (ALF25, ALF50, and ALF75); and three white clover treatments combining this groundcover and each of $25 \%, 50 \%$, or $75 \%$ of the recommended rate of inorganic fertilizer (WC25, WC50, and WC75). The fertilizer used was a granular formulation of ammonium sulfate $(21 \% \mathrm{~N})$ applied manually around trees in each plot at the beginning of the growing season. The rates of fertilizer applied were $135 \mathrm{~kg} \mathrm{~N} / \mathrm{ha}$ for bare ground plots and $33.75,67.5$, and $101.25 \mathrm{~kg} \cdot \mathrm{ha}^{-1}$ for alfalfa and white clover plots fertilizer at $25 \%, 50 \%$, and $75 \%$, respectively.

BG100 plots were sprayed with glyphosate (Roundup Pro) at rate of $32 \mathrm{oz} / \mathrm{gal}$ twice during each growing season for complete control of emerging weed populations. A clear 2-foot band (1 foot on each side) was maintained with the same herbicide application along tree rows in cover crop plot to reduce competition between groundcovers and trees.

Cover crops were mowed every 2 weeks during the growing seasons 2009 and 2010 using a mower equipped with side discharge and the cut residues were returned as mulch to the ground.

\section{Measurements}

Soil nitrate. Soil samples from two profiles, 0 to $15 \mathrm{~cm}$ and 15 to $30 \mathrm{~cm}$, were taken at two random locations within each plot using a soil auger in mid May and late August of each growing season for analysis of mineral $\mathrm{N}$ content. The soil samples were placed in zip-lock bags, stored in an ice-loaded cooler $\left(4^{\circ} \mathrm{C}\right)$, and transported to the laboratory where they were refrigerated until analysis. Samples were mixed thoroughly and a subset of $\approx 5 \mathrm{~g}$ of the soil extracted with potassium chloride. The extracts were then filtered before analysis on a SAN++ segmented flow analyzer (Skalar Inc., Atlanta, GA).

Leachate collection and analysis. Suction lysimeters (Model 1900L48-B02M2; Soil Moisture Measurement Corp., Santa Barbara, CA) were installed to reach 3 -foot depth in the center of each plot to collect leachate below the root zone for determination of nutrient leaching. The drainage was collected once a week, its volume recorded, and the sample transported under cold storage to the laboratory for further analysis. Aliquots from all plots were analyzed on the SAN++ segmented flow analyzer (Skalar Inc.) to determine their nitrate concentration and the total mineral $\mathrm{N}$ lost for the week.

Tissue analyses. In late August in both 2009 and 2010, needles were randomly collected from each plot for nutrient analysis. The needles were oven-dried at $65{ }^{\circ} \mathrm{C}$ for at least $2 \mathrm{~d}$ and ground into a fine powder. Approximately $0.3 \mathrm{~g}$ of material was placed into a $75-\mathrm{mL}$ digestion tube and digested with a mixture of sulfuric acid $(4.5 \mathrm{~mL})$ and hydrogen peroxide $(1.5 \mathrm{~mL})$. A digestion blank was included for verification. Samples were predigested for $2 \mathrm{~h}$ and placed into a block digester (AIM600 Block Digestion System) at $340 \pm 10{ }^{\circ} \mathrm{C}$ for heat digestion under a programmed temperature schedule.
Total $\mathrm{N}$ was determined as described by Wilson et al. (2010). Aliquots from the digested solution were buffered and chlorinated after dialysis to form a chemical complex measured at $660 \mathrm{~nm}$ on a SAN++ segmented flow analyzer (Skalar Inc.).

Morphological measurements. Tree height and root collar diameter (RCD) were measured with a tape and a digital caliper at the beginning (early May) and end (late August) of each growing season. Tree height growth and RCD expansion were calculated as the difference between the initial and final measurements.

\section{Data analysis}

Morphological data, foliar $\mathrm{N}$, and soil nitrate concentrations were analyzed by twoway analysis of variance to test the effect of the treatments on growth, foliar $\mathrm{N}$, and soil fertility. The means were separated by a least significant difference test with $\alpha<0.05$. Pairwise comparison was run to compare each groundcover/fertilizer rate combination with the conventional standard. The leaching data were analyzed using the mixed model for repeated-measures procedures. All data analyses were performed using Systat 13 software (Systat Software, Inc., Chicago, IL). A level of significance of $\alpha<0.05$ was used to determine statistical significance.

\section{Results}

Average temperatures and rainfall. Rainfall patterns were similar in both years of the study. The total rainfall during the growing season was $424.7 \mathrm{~mm} \mathrm{(2009)}$ and $407.1 \mathrm{~mm}$ (2010).

Table 1. Average monthly temperatures and total rainfall during the 2009 and 2010 growing seasons.

\begin{tabular}{lllrrrrr}
\hline & & & May & June & July & Aug. & Sept. \\
\hline 2009 & Average & Maximum & 20.5 & 24.8 & 24.9 & 25.5 & 23.5 \\
& temperature $\left({ }^{\circ} \mathrm{C}\right)$ & Minimum & 7.8 & 13.4 & 13.4 & 14.9 & 10.7 \\
& Rainfall $(\mathrm{cm})$ & & 10.9 & 12.62 & 6.07 & 10.46 & 2.41 \\
& & & & & & & \\
2010 & Average & Maximum & 28.02 & 26.47 & 27.93 & 27.51 & 23.08 \\
& temperature $\left({ }^{\circ} \mathrm{C}\right)$ & Minimum & 15.27 & 15.17 & 16.74 & 14.54 & 11.26 \\
& Rainfall $(\mathrm{cm})$ & & 12.89 & 10.1 & 6.81 & 3.74 & 7.17 \\
\hline
\end{tabular}

Table 2. Tree growth and root collar diameter in 2009 and 2010 from plots treated with each cover crop species choice and fertilizer treatments.

\begin{tabular}{|c|c|c|c|c|c|c|c|}
\hline & \multirow[b]{2}{*}{ Treatment } & \multicolumn{2}{|c|}{2009} & \multicolumn{2}{|c|}{2010} & \multicolumn{2}{|c|}{$\begin{array}{l}2 \text { years } \\
\text { cumulative }\end{array}$} \\
\hline & & $\begin{array}{l}\mathrm{Ht} \\
(\mathrm{cm})\end{array}$ & $\begin{array}{l}\mathrm{RCD} \\
(\mathrm{mm})\end{array}$ & $\begin{array}{l}\mathrm{Ht} \\
(\mathrm{cm})\end{array}$ & $\begin{array}{l}\mathrm{RCD} \\
(\mathrm{mm})\end{array}$ & $\begin{array}{l}\mathrm{Ht} \\
(\mathrm{cm})\end{array}$ & $\begin{array}{l}\mathrm{RCD} \\
(\mathrm{mm})\end{array}$ \\
\hline \multirow[t]{4}{*}{$\overline{\mathrm{ALF}}$} & BG100 & $11.70 \pm 0.91 \mathrm{a}^{\mathrm{z}}$ & $3.94 \pm 0.41 \mathrm{a}$ & $18.41 \pm 1.47 \mathrm{a}$ & $14.02 \pm 0.83 \mathrm{a}$ & 30.11 & 17.96 \\
\hline & ALF25 & $12.76 \pm 1.23 \mathrm{a}$ & $4.87 \pm 0.34 \mathrm{a}$ & $20.86 \pm 1.81 \mathrm{a}$ & $15.78 \pm 0.65 \mathrm{a}$ & 33.62 & 20.67 \\
\hline & ALF50 & $14.14 \pm 1.12 \mathrm{a}$ & $5.17 \pm 0.37 \mathrm{a}$ & $19.20 \pm 1.68 \mathrm{a}$ & $13.31 \pm 0.77 \mathrm{a}$ & 33.34 & 18.48 \\
\hline & $\begin{array}{l}\text { ALF75 } \\
P\end{array}$ & $\begin{array}{c}11.11 \pm 1.07 \mathrm{a} \\
P=0.214\end{array}$ & $\begin{array}{c}3.92 \pm 0.42 \mathrm{a} \\
P=0.054\end{array}$ & $\begin{array}{c}19.77 \pm 1.60 \mathrm{a} \\
P=0.757\end{array}$ & $\begin{array}{c}14.24 \pm 0.93 \mathrm{a} \\
P=0.155\end{array}$ & 30.88 & 18.16 \\
\hline \multirow[t]{4}{*}{$\mathrm{WC}$} & BG100 & $11.70 \pm 0.91 \mathrm{a}$ & $3.94 \pm 0.41 \mathrm{a}$ & $18.41 \pm 1.47 \mathrm{~b}$ & $14.02 \pm 0.83 \mathrm{a}$ & 30.11 & 17.96 \\
\hline & WC25 & $7.29 \pm 0.76 b$ & $4.24 \pm 0.41 \mathrm{a}$ & $11.94 \pm 1.19 \mathrm{a}$ & $6.97 \pm 0.94 b$ & 19.22 & 11.62 \\
\hline & WC50 & $10.60 \pm 1.05 \mathrm{ac}$ & $4.83 \pm 0.51 \mathrm{a}$ & $13.76 \pm 1.69 \mathrm{ab}$ & $11.78 \pm 0.91 \mathrm{a}$ & 24.36 & 16.61 \\
\hline & $\begin{array}{l}\text { WC75 } \\
P\end{array}$ & $\begin{array}{c}8.02 \pm 0.60 \mathrm{bc} \\
P=0.001\end{array}$ & $\begin{array}{c}4.60 \pm 0.33 \mathrm{a} \\
P=0.462\end{array}$ & $\begin{array}{c}13.78 \pm 1.02 \mathrm{ab} \\
P=0.008\end{array}$ & $\begin{array}{c}12.18 \pm 0.98 \mathrm{a} \\
P=0.000\end{array}$ & 21.8 & 18.85 \\
\hline
\end{tabular}

$\mathrm{RCD}=$ root collar diameter; BG100 = bare ground with $100 \%$ nitrogen $(\mathrm{N})$; ALF25 = alfalfa with $25 \% \mathrm{~N}$; ALF50 = alfalfa with $50 \% \mathrm{~N}$; ALF75 = alfalfa with $75 \% \mathrm{~N}$; WC25 = white clover with $25 \% \mathrm{~N}$; WC $50=$ white clover with $50 \% \mathrm{~N}$; WC75 = white clover.

Data were analyzed by analysis of variance and pairwise comparison using the Turkey's honestly significant difference test.

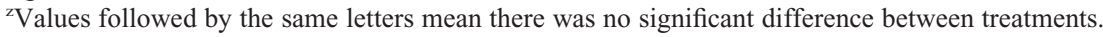


Monthly rainfall totals varied from $24.1 \mathrm{~mm}$ to $126.2 \mathrm{~mm}$ in 2009 and 37.4 to $128.9 \mathrm{~mm}$ in 2010 (Table 1). Average maximum and minimum temperatures were slightly higher in 2010 compared with 2009 (Table 1). Average maximum temperatures varied from 23.08 to $28.02^{\circ} \mathrm{C}$ in 2010 compared with 20.5 to $25.5^{\circ} \mathrm{C}$ in 2009, whereas average minimum varied from 11.26 to $16.74{ }^{\circ} \mathrm{C}$ in 2009 compared with 7.8 to $14.9^{\circ} \mathrm{C}$ in 2010 .

Tree growth. Tree morphological response was significantly higher in 2010 compared with 2009 with greater height and RCD growth in all treatments (Table 2). The height growth response to alfalfa and fertilizer cropping system treatments was generally higher compared with BG100 control treatments (except ALF75 in 2009) for both 2009 and 2010. However, statistical analyses indicated that differences in height were not statistically significant $(P=0.214$ and $P=0.757$ in 2009 and 2010, respectively). Conversely, the height growth response in white clover treatments was statistically significant in both years $(P=0.001$ and $P=0.008$ in 2009 and 2010) with white clover treatments generally having less height growth compared with BG100 control treatments.

Diameter growth response was similar to height for alfalfa treatments with RCD growth values statistically similar to BG100 control treatments in both 2009 and $2010(P=0.054$ and $P=0.155$, respectively). White clover treatments had similar RCD growth responses to BG100 control in $2009(P=0.462)$, but in 2009, RCD growth response was significantly lower in white clover treatments compared with BG100 control plots $(P<0.001)$.

Tree foliar nitrogen concentrations. There was no difference in fraser fir foliar $\mathrm{N}$ concentrations between ALF treatments and BG100 in both years $(P=0.555$ in 2009 and $P=0.774$ in 2010). A similar trend was observed for trees in white clover treatments in 2010. However, measurements of trees' foliar nutrient concentrations in 2009 were statistically $(P=0.014)$ different as a result of trees in WC50 plots having lower foliar $\mathrm{N}$ than other treatments in the same group (Fig. 1). In 2009 , foliar N concentrations of tree specimens in BG100 plots were generally higher than WC treatments (Fig. 1).

Soil nitrate concentration and bulk density. Soil nitrate concentrations at the upper soil profile $(0$ to $15 \mathrm{~cm})$ were generally higher in cover crop treatments (except ALF25 treatment in 2010) compared with BG100 control plots in both years. BG100 plots had $45 \mu \mathrm{g} \cdot \mathrm{g}^{-1}$ (2009) and $38.6 \mu \mathrm{g} \cdot \mathrm{g}^{-1}$ in 2010. Alfalfa nitrate concentrations varied from 50.39 to 57.5 $\mu \mathrm{g} \cdot \mathrm{g}^{-1}$ in 2009 and from 33.5 to $46.7 \mu \mathrm{g} \cdot \mathrm{g}^{-1}$ in 2010. Nitrate levels in white clover plots were much higher than alfalfa plots, varying from 82.2 to $103.2 \mu \mathrm{g} \cdot \mathrm{g}^{-1}$ in 2009 and 38.6 to $91.5 \mu \mathrm{g} \cdot \mathrm{g}^{-1}$ in 2010 . However, as a result of the very high variability in the data, the differences were not statistically significant (Table 3). In the deeper profile (15 to $30 \mathrm{~cm}$ ), soil nitrate concentrations were much lower than those determined in the upper profile and varied from 8.1 to $12.2 \mu \mathrm{g} \cdot \mathrm{g}^{-1}$ in 2009 and 4.3
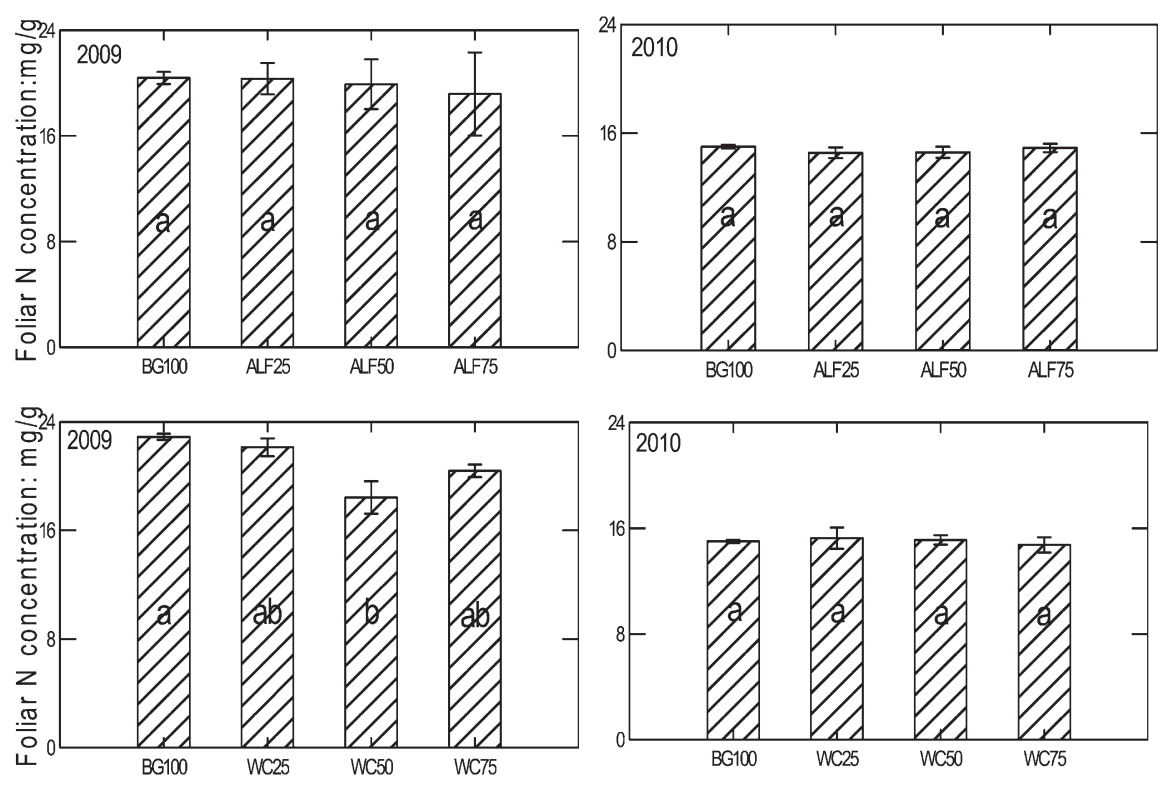

Fig. 1. Foliar nitrogen concentration as affected by cropping system treatments. BG100 = bare ground with $100 \%$ nitrogen $(\mathrm{N})$; ALF25 = alfalfa with $25 \% \mathrm{~N}$; ALF50 = alfalfa with $50 \% \mathrm{~N}$; ALF75 = alfalfa with $75 \% \mathrm{~N}$; WC25 = white clover with $25 \% \mathrm{~N}$; WC50 =s white clover with $50 \% \mathrm{~N} ; \mathrm{WC} 75=$ white clover. Data were analyzed by analysis of variance and pairwise comparison using the Turkey's honestly significant difference test. Except for white clover treatments in 2009, there was generally no treatment effect on foliar $\mathrm{N}$ concentration except in 2009 , when WC had significantly lower foliar $\mathrm{N}$ than $\mathrm{BG}(P=$ 0.016 ). In values followed by the same letters mean, there was no significant difference between treatments.

Table 3. Soil nitrate concentrations $\left(\mu \mathrm{g} \cdot \mathrm{g}^{-1}\right)$ in 2009 and 2010 in plots treated with each cover crop species and fertilizer treatments.

\begin{tabular}{ccccccc}
\hline & & \multicolumn{2}{c}{0 to $15 \mathrm{~cm}$} & & \multicolumn{2}{c}{15 to $30 \mathrm{~cm}$} \\
\cline { 3 - 4 } \cline { 5 - 6 } & Treatment & 2009 & 2010 & & 2009 & 2010 \\
\hline ALF & BG100 & $45.00 \pm 3.07 \mathrm{a}^{2}$ & $8.15 \pm 0.25 \mathrm{a}$ & & $38.60 \pm 1.04 \mathrm{a}$ & $4.30 \pm 0.06 \mathrm{a}$ \\
& ALF25 & $57.51 \pm 1.47 \mathrm{a}$ & $10.38 \pm 0.13 \mathrm{a}$ & & $33.50 \pm 0.44 \mathrm{a}$ & $6.34 \pm 0.09 \mathrm{a}$ \\
& ALF50 & $71.87 \pm 0.74 \mathrm{a}$ & $12.27 \pm 0.90 \mathrm{a}$ & & $44.94 \pm 0.79 \mathrm{a}$ & $5.85 \pm 0.16 \mathrm{a}$ \\
& ALF75 & $50.39 \pm 3.11 \mathrm{a}$ & $9.09 \pm 0.52 \mathrm{a}$ & & $46.70 \pm 1.57 \mathrm{a}$ & $5.53 \pm 0.07 \mathrm{a}$ \\
& $P$ & $P=0.473$ & $P=0.751$ & & $P=0.356$ & $P=0.125$ \\
& & & & & \\
WC & & & & & \\
& BG100 & $45.00 \pm 3.07 \mathrm{a}$ & $8.15 \pm 0.25 \mathrm{a}$ & & $38.60 \pm 1.04 \mathrm{a}$ & $4.30 \pm 0.06 \mathrm{a}$ \\
& WC25 & $125.96 \pm 8.29 \mathrm{a}$ & $9.35 \pm 0.43 \mathrm{a}$ & & $48.33 \pm 0.93 \mathrm{a}$ & $4.83 \pm 0.04 \mathrm{a}$ \\
& WC50 & $103.24 \pm 3.88 \mathrm{a}$ & $10.78 \pm 0.37 \mathrm{a}$ & & $91.53 \pm 8.40 \mathrm{a}$ & $5.71 \pm 0.13 \mathrm{a}$ \\
& WC75 & $82.20 \pm 1.62 \mathrm{a}$ & $10.78 \pm 0.49 \mathrm{a}$ & & $73.08 \pm 3.21 \mathrm{a}$ & $5.24 \pm 0.05 \mathrm{a}$ \\
& $P$ & $P=0.220$ & $P=0.782$ & & $P=0.429$ & $P=0.176$ \\
\hline
\end{tabular}

BG100 = bare ground with $100 \%$ nitrogen $(\mathrm{N}) ;$ ALF25 = alfalfa with $25 \% \mathrm{~N} ;$ ALF $50=$ alfalfa with $50 \% \mathrm{~N}$; ALF75 = alfalfa with $75 \% \mathrm{~N} ;$ WC25 = white clover with $25 \% \mathrm{~N} ;$ WC50 = white clover with $50 \% \mathrm{~N} ; \mathrm{WC75}$ - white clover.

The soil samples were collected on 25 Aug. in 2009 and 24 Aug. in 2010.

Data were analyzed by analysis of variance and pairwise comparison using the Turkey's honestly significant difference test.

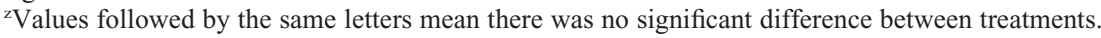

to $6.34 \mu \mathrm{g} \cdot \mathrm{g}^{-1}$ in 2010 for alfalfa and 8.1 to $10.8 \mu \mathrm{g} \cdot \mathrm{g}^{-1}$ in 2009 and 4.3 to $5.7 \mu \mathrm{g} \cdot \mathrm{g}^{-1}$ in 2010 for white clover. There was no statistical difference between BG100 control and alfalfa or white clover treatments.

Soil bulk density values (Table 4 ) remained statistically similar between BG100 plots and cover crop treatments at the end of the 2009 and 2010 seasons $(P=0.439$ for 2009 and $P=$ 0.741 for 2010), suggesting no short-term effect of the cover crop species on soil bulk density.

Drainage volumes and nitrogen content. Cumulative leachate volumes were statistically similar in $2009(P=0.627)$ and 2010 $(P=0.913)$, indicating that cropping system
Table 4. Soil Bulk density as affected by the cover crop species.

\begin{tabular}{lcc}
\hline & \multicolumn{2}{c}{ Soil bulk density $\left(\mathrm{g} \cdot \mathrm{cm}^{-3}\right)$} \\
\hline & 2009 & 2010 \\
\hline BG & $1.311 \pm 0.066 \mathrm{a}^{2}$ & $1.115 \pm 0.111 \mathrm{a}$ \\
ALF & $1.130 \pm 0.128 \mathrm{a}$ & $1.190 \pm 0.027 \mathrm{a}$ \\
WC & $1.285 \pm 0.109 \mathrm{a}$ & $1.125 \pm 0.055 \mathrm{a}$ \\
\hline
\end{tabular}

$\mathrm{BG}=$ bare ground; ALF - alfalfa; $\mathrm{WC}=$ white clover. Each value represents the average of three replicates. Data were analyzed by analysis of variance and pairwise comparison using the Turkey's honestly significant difference test.

There was no cover crop species effect on soil bulk density in both years $(P=0.438$ for 2009 and $P=$ 0.741 for 2010).

${ }^{2}$ Values followed by the same letters mean there was no significant difference between treatments. 
treatments or cover crop species did not affect the water drainage through the soil profiles. Volumes collected ranged from $5471 \mathrm{~mL}$ to $8039 \mathrm{~mL}$ in 2009 and $4262 \mathrm{~mL}$ to $7296 \mathrm{~mL}$ in 2010 (Table 5). As the growing season progressed, the cumulative nitrate $\mathrm{N}$ leached (Fig. 2) was consistently higher for BG100 control compared with all alfalfa treatments in both years. However, in white clover treatments, the cumulated nitrogen leached in WC25 treatment was the highest in 2009, whereas the WC75 treatment had the highest leaching $\mathrm{N}$ content curve in 2010.

\section{Discussion}

Effect of cropping system on tree growth and productivity. In this study, the growth

Table 5. Cumulated drainage volume collected below the root zone in the various treatments in 2009 and 2010.

\begin{tabular}{lll}
\hline & \multicolumn{2}{c}{ Volume $(\mathrm{mL})$} \\
\cline { 2 - 3 } & \multicolumn{1}{c}{2009} & \multicolumn{1}{c}{2010} \\
\hline BG100 & $6934 \pm 1052 \mathrm{a}^{\mathrm{z}}$ & $6484 \pm 1017 \mathrm{a}$ \\
ALF25 & $5471 \pm 802 \mathrm{a}$ & $4262 \pm 582 \mathrm{a}$ \\
ALF50 & $7621 \pm 609 \mathrm{a}$ & $6458 \pm 1431 \mathrm{a}$ \\
ALF75 & $6448 \pm 1372 \mathrm{a}$ & $7296 \pm 2230 \mathrm{a}$ \\
WC25 & $6449 \pm 826 \mathrm{a}$ & $5435 \pm 1205 \mathrm{a}$ \\
WC50 & $8039 \pm 909 \mathrm{a}$ & $6453 \pm 2318 \mathrm{a}$ \\
WC75 & $7063 \pm 1113 \mathrm{a}$ & $5648 \pm 935 \mathrm{a}$
\end{tabular}

BG100 = bare ground with $100 \%$ nitrogen $(\mathrm{N})$; ALF25 = alfalfa with $25 \% \mathrm{~N}$; ALF50 = alfalfa with $50 \% \mathrm{~N}$; ALF75 = is alfalfa with $75 \% \mathrm{~N}$; WC25 = white clover with $25 \% \mathrm{~N}$; WC50 = white clover with $50 \% \mathrm{~N}$; WC75 = white clover.

Data were analyzed by analysis of variance and pairwise comparison using the Turkey's honestly significant difference test. There was no treatment effect on cumulative leachate volume in $2009(P=$ $0.627)$ and $2010(P=0.913)$.

${ }^{\mathrm{z}}$ Values followed by the same letters mean there was no significant difference between treatments.
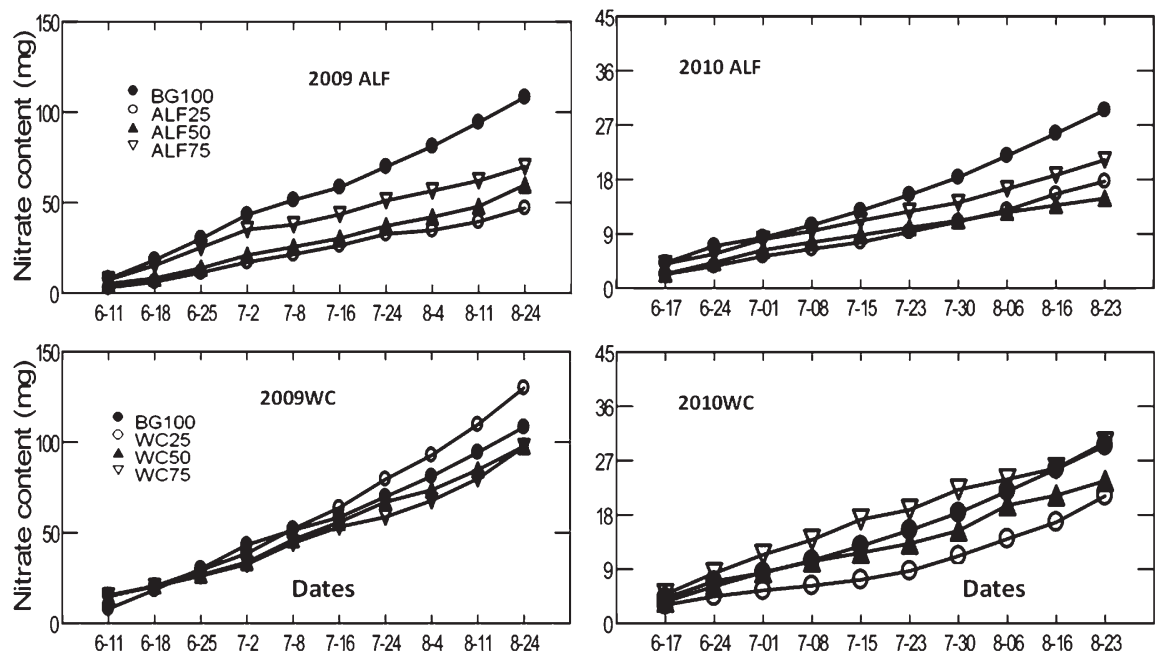

Fig. 2. Cumulated nitrate loss in 2009 and 2010 as affected by different cropping systems. BG100 = bare ground with $100 \%$ nitrogen $(\mathrm{N})$; ALF25 = alfalfa with $25 \% \mathrm{~N}$; ALF50 = alfalfa with $50 \% \mathrm{~N}$; ALF75 = alfalfa with $75 \% \mathrm{~N}$; WC25 = white clover with $25 \% \mathrm{~N}$; WC50 = white clover with $50 \% \mathrm{~N}$; WC75= white clover. Data were analyzed by analysis of variance with repeated measures procedure. There was a significant treatment effect for alfalfa treatments in $2009(P=0.056)$ and $2010(P=0.862)$ and white clover in $2009(P=0.725)$ and $2010(P=0.771)$.
In the white clover-based cropping systems of the current study, height and diameter growth responses were significantly lower than the conventional treatment. Such growth inhibition is likely the result of increased competition for resources needed for height and diameter expansion. The fact that foliar $\mathrm{N}$ concentrations were similar in the conventional control system and both cover crop species cropping systems suggest that the reduced morphological development observed in white clover plots was caused by limiting factors other than N. Previous work has shown that the competition for soil moisture can lead to depressed growth (Wilson et al., 2010). Tree diameter growth has been reported to be very sensitive to competition with cover crops (Meyer et al., 1992; Welker and Glenn, 1989). Low-diameter growth responses in trees as observed in white clover-based systems in this study have been associated with competition for moisture caused by groundcover that can induce excessive absorption of soil moisture (Pedersen et al., 2009).

Effect on soil density and nitrate- $N$ fertility. Soil mineral nitrate- $N$ concentrations were generally higher in 2009 compared with 2010 (Table 3). The reasons for lower levels of soil nitrate- $\mathrm{N}\left(\mathrm{NO}_{3}{ }^{-}-\mathrm{N}\right)$ in 2010 are unknown, but warmer spring and summer temperatures may have caused intensive decomposition and mineralization of the green manure from the cover crops during the growing season, leading to improved uptake and/or leaching resulting in lower soil $\mathrm{NO}_{3}{ }^{-}-\mathrm{N}$ levels toward the end of the growing season when samples were taken.

In both years of the study, although the cover crop-based cropping system had higher soil $\mathrm{NO}_{3}{ }^{-}-\mathrm{N}$ concentrations, there was no significant effect of cropping systems on soil mineral $\mathrm{NO}_{3}{ }^{-}-\mathrm{N}$ at the two profiles sampled in the study. This is an indication that the green manure decomposition and mineralization produced enough mineral $\mathrm{NO}_{3}{ }^{-} \mathrm{N}$ to more than compensate for the lower rate of inorganic fertilization applied. This finding is consistent with Sanchez et al. (2003) who found increased soil mineral $\mathrm{N}$ levels when combining groundcovers with full-rate $\mathrm{N}$ fertilization. Several soil and plant factors are known to determine green manure decomposition. Soil factors include texture, acidity, microbial activity, and soil fertility (Fageria, 2007; Thonnissen et al., 2000). Main plant factors are the carbon/ $\mathrm{N}$ and lignin/ $\mathrm{N}$, (lignin + polyphenol)/N ratios (Fageria, 2007; Gil and Fick, 2001). The lack of difference in soil mineral $\mathrm{N}$ in our study indicates either similarities for these factors between the various treatments for each system tested or nutrient flow patterns out of the soil profile resulting in similar residual soil $\mathrm{N}$ concentrations. Both alfalfa and white clover have very low carbon/ $\mathrm{N}$ ratios that will make them mineralize rather quickly once returned to the ground as green manure (Fageria, 2007). In addition, increases in $\mathrm{N}$ pools in the soil can increase the $\mathrm{N}$ mineralization, leading to large pools of highly mobile forms of $\mathrm{N}$ in the soil (Schroth et al., 2001). Because the total amount of green 
manure produced in each species of cover crop was similar for all combination treatments, it can be suggested that the fast decomposition of this material enhanced the $\mathrm{N}$ mineralization, leading to enhanced uptake and leaching below the root zone. Furthermore, the manuring process used in this study that promotes continuous decomposition and mineralization throughout the season and can lead to synchrony between mineral $\mathrm{N}$ release and $\mathrm{N}$ uptake by trees leading to low residual soil mineral $\mathrm{N}$.

Effect of cropping system on nitrogen leaching. In this study, there was surprisingly no difference in drainage volumes collected between cover crop treatments and the bare ground conventional treatment. It was expected that total volumes collected would be significantly different because of enhanced moisture uptake in cover crop plots or increased evaporation in bare ground treatments. The lack of difference indicates either an excellent distribution of rainfall in the area during both years of the study or a mutual cancellation of these opposing effects leading to similar water drainage below the root zone in all treatments. This is consistent with previous work that found no apparent effect on drainage volume in cover crops treatments (Davies et al., 1996; Kirchmann and Bergström, 2001; Macdonald et al., 2005; Meisinger et al., 1991). Nitrate leaching was reduced in alfalfa plots compared with bare ground control and increasing the $\mathrm{N}$ application rates in combination with the alfalfa groundcover did not increase the $\mathrm{N}$ leaching losses at any stage of the experiment. The result obtained was opposite in white clover plots where the groundcover combined with $75 \%$ or $50 \%$ of the rate of conventional fertilization resulted in increased nitrate leaching.

In complex intercropped systems, the amount of $\mathrm{N}$ scavenged depends on several factors, including weather, soil water, soil type, cover crop species, and cover crop growth (Sattell et al., 1999). Therefore, the different nitrate leaching response can be attributed to the species characteristics. Alfalfa has the ability to develop deep root systems quickly and is well known for its ability to scavenge mineral N (Mathers et al., 1975; Owens et al., 1994; Rasse et al., 1999), hence the low nitrate loss observed in alfalfa treatments.

The opposite trend observed in white clover could be the result of a number of factors, including a poor cover crop root system in white clover compared with alfalfa, reduced tree nitrate uptake making more nitrate available in the system, or a better mineralization rate leading to excessive soil nitrate production and increased leaching below the root zone.

\section{Conclusion}

The productivity of these systems, measured as height and diameter growth, was similar in alfalfa-based cropping systems compared with the conventional production system as a result of optimal growing conditions when combining regular mulching with low inorganic fertilizer applications. The positive growth result obtained in alfalfa cropping systems was supported by excellent foliar $\mathrm{N}$ concentrations, similar soil mineral $\mathrm{N}$, and reduced nitrate leaching content. The picture was slightly different in white clover-based cropping systems where reduced height and diameter growth was sometimes observed as a result of competition for non-N soil resources. Slightly higher nitrate leaching was also observed in some white clover cropping systems, suggesting an imbalance between mineral $\mathrm{N}$ availability and uptake. Based on the results obtained in this study, white clover may be too competitive a cover crop compared with alfalfa. Additional tests including other cover crops in addition to the two species included in the present study should be conducted to evaluate their competitiveness before they can be included in cropping system. We conclude that if the competition between cover crops and trees can be controlled, the use of a cover crop can be combined with very low rates of inorganic fertilizers to achieve several benefits such as enhanced tree growth and sufficient foliar $\mathrm{N}$, while reducing the adverse impacts to groundwater systems. Further studies related to the mineralization rate of the various species under these conditions, other macronutrients, and competition for other soil resources are needed before any conclusion can be made about the use of these cropping systems under operational conditions.

\section{Literature Cited}

Bakht, J.M.S., M.T. Jan, and Z. Shah. 2009. Influence of crop residue management, cropping system and $\mathrm{N}$ fertilizer on soil $\mathrm{N}$ and $\mathrm{C}$ dynamics and sustainable wheat (Triticum aestivum L.) production. Soil Tillage Res. 104:233-240.

Baumgartner, K., K.L. Steenwerth, and L. Veilleux. 2008. Cover-crop systems affect weed communities in a California vineyard. Weed Sci. 56 : 596-605.

Brinsfield, R.B. and K.W. Staver. 1991. Use of cereal grain cover crops for reducing groundwater nitrate contamination in the Chesapeake Bay region, p. 79-82. In: Hargrove, W.L. (ed.). Cover crops for clean water. Soil Water Conserv. Soc., Ankeny, IA.

Casper, B.B. and R.B. Jackson. 1997. Plant competition underground. Annu. Rev. Ecol. Syst. 28: $545-570$.

Costello, M.J. 2010. Growth and yield of cultivated grape with native perennial grasses nodding needlegrass or California barley as cover crops. HortScience 45:154-156.

Davies, D.B., T.W.D. Garwood, and A.D.H. Rochford. 1996. Factors affecting nitrate leaching from a calcareous loam in East Anglia. J. Agr. Sci. 126: $75-86$.

Drinkwater, L.E., P. Wagoner, and M. Sarrantonio. 1998. Legume-based cropping systems have reduced carbon and nitrogen losses. Nature 396: 262-265.

Fageria, N.K. 2007. Green manuring in crop production. J. Plant Nutr. 30:691-719.

Gerry, A.K. and S.D. Wilson. 1995. The influence of initial size on the competitive responses of six plant species. Ecology 76:272-279.

Gil, J.L. and W.H. Fick. 2001. Soil nitrogen mineralization in mixtures of eastern gamagrass with alfalfa and red clover. Agron. J. 93:902-910.

Giller, K.E. and K.J. Wilson. 2000. Nitrogen fixation in tropical systems. CAB International, Wallingford, UK.
Hanninen, K.S. 1998. Effects of clovers as vegetative ground cover on the growth of red birch on nursery field production. J. Hort. Sci. Biotechnol. 73:393-398.

Hargrove, W.L. (ed.). 1991. Cover crops for clean water. Proc. of an international conference. West Tennessee Experiment Station, 9-11 Apr. 1991. Soil and Water Conservation Society.

Juo, A.S.R., A. Dabiri, and K. Franzluebbers. 1995. Acidification of a kaolinitic Alfisol under continuous cropping with nitrogen fertilization in West Africa. Plant Soil 171:245-253.

Kirchmann, H. and L. Bergström. 2001. Do organic farming practices reduce nitrate leaching? Commun. Soil Sci. Plant Anal. 32:997-1028.

Köchy, M. and S.D. Wilson. 1997. Litter decomposition and nitrogen dynamics in aspen forest and mixed-grass prairie. Ecology 78:732-739.

Kourik, R. 1986. Grow your own fertilizers: Cover crops and green manures, p. 382. In: Designing and maintaining your edible landscape naturally. Metamorphic Press, Santa Rosa, CA.

Kuhn, B.F. and H.L. Pedersen. 2009. Cover crop and mulching effects on yield and fruit quality in unsprayed organic apple production. Europ. J. Hort. Sci. 74:247-253.

Macdonald, A.J., P.R. Poulton, M.T. Howe, K.W.T. Goulding, and D.S. Powlson. 2005. The use of cover crops in cereal-based cropping systems to control nitrate leaching in SE England. Plant Soil 273:355-373.

MacRae, R.J. and G.R. Mehuys. 1985. The effect of green manuring on the physical properties of temperate-area soils. Adv. Soil Sci. 3:71-94.

Mathers, A.C., B.A. Stewart, and B. Blair. 1975. Nitrate-nitrogen removal from soil profiles by alfalfa. J. Environ. Qual. 4:403-405.

Meisinger, J.J., W.L. Hargrove, J.R. Mikkelsen, and V.W. Benson. 1991. Effects of cover crops on groundwater quality, p. 57-68. In: Hargrove, W.L. (ed.). Cover crops for clean water. Soil and Water, Ankeny, IA.

Meyer, J.R., E.I. Zehr, R.L. Meagher, Jr., and S.K. Salvo. 1992. Survival and growth of peach trees and pest populations in orchard plots managed with experimental ground covers. Agric. Ecosyst. Environ. 41:353-363.

Owens, L.B., W.M. Edwards, and R.W. Van Keuren. 1994. Groundwater nitrate levels under fertilized grass and grass legume-pastures. J. Environ. Qual. 23:752-758.

Pedersen, A., K. Thorup-Kristensen, and L.S. Jensen. 2009. Simulating nitrate retention in soils and the effect of catch crop use and rooting pattern under the climatic conditions of Northern Europe. Soil Use Manage. 25:243-254.

Radovich, T., L.J. Cox, J. Sugano, and T. Idol. 2009. Benefits and costs of using perennial peanut as living mulch for fruit trees in Hawaii. College of Tropical Agriculture and Human Resources (CTAHR). SCM, 27 Aug. 2009.

Rasse, D.P., A.J.M. Smucker, and O. Schabenberger. 1999. Modifications of soil nitrogen pools in response to alfalfa root systems and shoot mulch. Agron. J. 91:471-477.

Reddy, K.N. 2001. Effects of cereal and legume cover crop residues on weeds, yield, and net return in soybean (Glycine max). Weed Technol. 15:660-668.

Sanchez, J.E., C.E. Edson, G.W. Bird, M.E. Whalon, T.C. Willson, R.R. Harwood, K. Kizilkaya, J.E. Nugent, W. Klein, A. Middleton, T.L. Loudon, D.R. Mutch, and J. Scrimger. 2003. Orchard floor and nitrogen management influences soil and water quality and tart cherry yields. J. Amer. Soc. Hort. Sci. 128:277-284.

Sattell, R., R. Dick, D. Hemphill, J. Selker, F. BrandiDohrn, H. Minchew, M. Hess, J. Sandeno, and 
S. Kaufman. 1999. Nitrogen scavenging: Using cover crops to reduce nitrate leaching in Western Oregon. Oregon cover crops, EM 8728, October.

Schroth, G., M.R.L. Rodrigues, and S.A. D'Angelo. 2000. Spatial patterns of nitrogen mineralization, fertilizer distribution and roots explain nitrate leaching from mature Amazonian oil palm plantation. Soil Use Manage. 16: 222-229.

Schroth, G., E. Salazar, and J.P. Da Silva. 2001. Soil nitrogen mineralization under tree crops and a legume cover crop in multi-strata agroforestry in central Amazonia: Spatial and temporal patterns. Exp. Agr. 37:253-267.
Shipley, P.R., J.J. Meisinger, and A.M. Decker. 1992. Conserving residual corn fertilizer nitrogen with winter cover crops. Agron. J. 84:869-896.

Shribbs, J.M. and W.A. Skroch. 1986. Influence of 12 ground cover systems on young 'Smoothee Golden Delicious' apples trees: II. Nutrition. J. Amer. Soc. Hort. Sci. 111:529-533.

Thonnissen, C., D.J. Midmore, J.J. Ladha, R.J. Holmer, and U. Schmidhalter. 2000. Tomato crop response to short-duration legume green manures in tropical vegetable systems. Agron. J. 85:673-680.

Vaughan, J.D. and G.K. Evanylo. 1998. Corn response to cover crop species, spring desiccation time, and residue management. Agron. J. 90:536-544.
Weiner, J., D.B. Wright, and S. Castro. 1997. Symmetry of below-ground competition between Kochia scoparia individuals. Oikos 79: 85-91.

Welker, W.V. and D.M. Glenn. 1989. Sod proximity influences the growth and yield of young peach trees. J. Amer. Soc. Hort. Sci. 114: 856-859.

Wilson, A.R., P. Nzokou, and B.M. Cregg. 2010. Ground covers in Fraser fir (Abies fraseri Pursh. Poir) production systems: Effects on soil fertility, tree morphology and foliar nutrient status. Europ. J. Hort. Sci. (In press).

Wilson, J.B. 1988. Shoot competition and root competition. J. Appl. Ecol. 25:279-296. 